JOURNAL OF SECURITY AND SUSTAINABILITY ISSUES

ISSN 2029-7017 print/ISSN 2029-7025 online

2019 September Volume 9 Number 1

http://doi.org/10.9770/jssi.2019.9.1(1)

Scopus

\title{
REGIONAL CONFLICTS AS AN ATTRIBUTE OF GLOBAL INSTABILITY
}

\author{
Vladimir Stepanovich Baturin ${ }^{1 *}$, Garifolla Esim ${ }^{2}$, Symbat Erkebaevich Shakirov ${ }^{3}$ \\ ${ }^{1}$ Karaganda State University of the name of academician E. A. Buketov, Karagandy, Kazakhstan \\ ${ }^{2,3}$ L. N. Gumilyov Eurasian National University, Astana, Kazakhstan
}

E-mail: ${ }^{1 *} v \_s b a t u r i n @ b k . r u$

Received 15 November 2018; accepted 18 June 2019; published 30 September 2019

\begin{abstract}
The article presents the nature of regional conflicts as one of the types of social conflicts in the context of traditional (naturalistic) and activity approaches. The authors reveal a number of conditions that determined the reasons for use of social conflicts in the second half of the 20th century, as well as the features of the increased demand for them in terms of solving the problems generated by contemporary globalization processes. Particular attention is paid to the threat posed by the attempts of a number of countries to use regional conflicts in order to demonstrate their power to the rest of the world. The article presents the analysis of the reasons contributing to the transformation of regional conflicts into an attribute of global instability, as well as considers the prospects of the formation of a multipolar world arrangement model, where the very possibility of regional conflicts could be minimized.
\end{abstract}

Keywords: regional conflict; the activity approach; conflictogenity; the conflict escalation; counteractivity; the subject-object paradigm; destabilization; uncontrollable chaos

Reference to this paper should be made as follows: Baturin, V.S.; Essim, G.; Shakirov, S.E. 2019. Regional conflicts as an attribute of global instability, Journal of Security and Sustainability Issues 9(1): 5-11. http://doi.org/10.9770/jssi.2019.9.1(1)

JEL Classifications: H55, O18, P48.

Additional disciplines: political sciences; sociology

\section{Introduction}

Today, globalization processes are increasingly demonstrating trends that indicate the emergence of global instability. The dynamics of these processes acquire a pronounced turbulent nature. In addition, against this background, the increased number of terrorist acts, carried out by members of various extremist groups and international terrorist organizations, has become a special threat to world. Their danger is greatly exacerbated by the fact that these actions are associated with a pronounced religious dominant. In this regard, the identification of the reasons for such a rapidly growing tendency to solve problems arising in society in the most radical way is not only purely theoretical issue, but also the problem of great practical importance. The acquired knowledge can be particularly relevant in connection with the response to the provocations and threats that today are represented by conflicts of a regional format.

In this regard, quite indicative is the attitude to the events of this kind, manifested, for example, in the Republic of Kazakhstan. Attention to them, both from the part of state and the professional community of philosophers, sociologists, psychologists, political scientists, and public members appears when they are already beginning to take a resonant nature. A clear proof of this fact, for example, can serve the conflict in Western Kazakhstan, which occurred in 2011 in Zhanaozen (Conflict in Western Kazakhstan, 2012) and the conflictogenic nature of the events that took place in the city of Temirtau of the Karaganda Region (Conflict in Temirtau: Chronic 
stage, 2012). Particularly alarming is the fact that "in the period from 2011 to 2016 in Kazakhstan, according to publicly available sources, there were more than 10 major terrorist acts" (Kasymov, 2018).

Western scientists have comprehensively studied the conditions, causes, and factors of social conflicts, their specifics, development stages, and functions in society. On this basis they have developed various conflict typologies. The following concepts have become particularly popular: "The general theory of conflict" (K. Boulding), "The positive-functional conflict" (L. Coser), "The conflict model of society" (R. Dahrendorf), "The international conflict as a special kind of social conflict" (K. Deutsch, K. Mitchell, B. Brody, R. Patnem, M. Hermann), and "The theory of fundamental negotiations" (G. Burton, R. Dahl, R. Fisher).

The problem of regional conflicts is extremely diverse, since they differ in forms, causes, etc. Thus, G. Turovsky notes the following types of conflicts arising at the regional level: institutional, or constitutional, which is a conflict between political institutions; intra-elite conflict between groups of interests; social conflict arising from tension or ill-conceived policies of local authorities; as well as ethnic and religious (interethnic) conflict, the subjects of which are ethnic (national) and/or confessional groups. (Turovsky, 2001).

In this regard, undoubtedly, knowledge and development of measures to prevent and resolve this kind of social upheaval involves creative, reflexive rethinking of what has already been developed in this area, and the identification of new concepts demonstrated by the realities of contemporary times. The question is what, in particular may indicate the occurrence of diverse conflicts, such as regional conflicts, asymmetric conflicts, complex conflicts, latent conflicts, hybrid warfare, etc. It seems the theory does not always keep up with what is happening in practice.

\section{Methods}

The qualitative content analysis of scientific literature from the problem field of the study was used as a research method. This approach allowed determining the methodology of problematisation of the "social conflict" phenomenon as the most effective way of its perception. Based on the problematisation methodology, an attempt is made to identify the main factors that escalate regional conflicts.

The research hypothesis. Analysis of regional conflicts as an attribute of global instability will be more effective when using the methodology of problematisation. At that, the processes of globalization and the external aggravation of conflicts in the region should be considered the main factors of regional conflicts escalation.

\subsection{Methodology of the problematisation of the "social conflict" phenomenon as an effective way of its cognition}

Speaking about the peculiarities when studying the essence of regional conflicts, as one of the varieties of social conflicts in general, it should be noted that they are traditionally considered within the format of naturalization of this social phenomenon. The essence of this approach is fully reflected by one of the provisions, according to which "the conflict is not fundamentally different from other natural and social phenomena" (Svetlov, 2012, p. 5). This means that in this case the cognition of a variety of social conflicts, such as regional conflicts, is carried out by analogy with any other natural or social object (e.g. Tvaronavičienė 2018a; Tvaronavičienė 2018b; Kazansky, Andrassy 2019; Turen et al. 2019; Prause et al. 2019). As practice shows, such a way of cognition of any phenomenon, i.e. getting an idea about it by "copying from nature", does not reliably guarantee that the essence of this phenomenon will be revealed to the end.

In this regard, an alternative to the methodology of naturalization of the phenomenon in the course of its cognition is the methodology of its problematisation. The peculiarity of problematisation is that it begins with the identification of system-forming factors that serve the basis for the origin of the very existence of this phenomenon, followed by the advancement of knowledge based on the logic of further formation and development of this very existence. 
The need to refer exactly to this methodology is largely due to the fact that here the main object of the study is exactly the nature of the relationship between the direct participants of joint activities, rather than the reason from which this activity arises, and outside of which, neither regional nor other social conflicts occur at all. At that, it is hard to avoid clashes of various people or all kinds of their collective formations, with needs, interests, etc., which are multidirectional in nature.

Naturally, this inevitably leads to the manifestation of resistance to such a vector of impact of one object (objects) from the other object (objects). "Counter-activity appears when coordination is not considered necessary, while the arisen mutual obstacle acts as a condition of erasing the confronting activity" (Anisimov, 2008, p. 141). Thus, counter-activity is a kind of social activity, when someone tries to "subordinate other activities to their needs without taking into account the features of interests of other activities" (Anisimov, 2008, pp. 250). And this very counter-activity can take a variety of forms - from a simple challenging the legality of the current situation in the most peaceful forms, up to the forced military confrontation. This, in fact, has served the basis to consider any manifestations of counter-activity, the clash of opposing interests, views, and aspirations; a serious disagreement, a heated argumentation, leading to the fight (Anisimov 1991). And the activity itself in this format of confrontation, initially assuming even a kind of subject-subject relationship, acquires a pronounced object-object character. "After all, the conflict is a kind of counter-activity of self-sufficient subjects committed completely disregarding the human essence in another person" (Baturin and Shakirov, 2014, p. 80).

In the context of this vision, on the one hand, the nature of the regional conflicts' emergence is largely due to the relative small-scale "erasure of certain types of confronting activities" carried out by the participants of collective activities (as a part) in relation to the social activity of the entire certain type of this community (as a whole). On the other hand, it is because of its small scale that the local (both in terms of time and the space) nature of its manifestation becomes the reason of confronting activities (Ushakov, p. 62).

The roots of the causes that contribute to the transformation of present-day regional conflicts into a basic attribute of global instability are largely due to the fact that certain social circles and society forces see them as a rather effective means of satisfying in practice their desire to "improve society". At that, this desire is not always openly advertised due to the fact that this "improvement" is carried out in favor of their own discretion, even despite all kinds of assurances to the contrary (Coser, 2000, pp. 34, 36).

The use of such a methodological basis allows one to look in general at the essence of regional conflicts as well as the peculiarities of their manifestation in the context of globalization from a slightly different perspective. Thus, all the above confirms the assumption that the use of the methodology of problematisation is effective when analyzing regional conflicts.

\subsection{Globalization processes as an escalation factor of regional conflicts}

As practice shows, it is globalization processes that today are a dominant factor in the escalation of conflictogenity, primarily in the social structures of the regional format. These processes, contributing to the internationalization of all economy sectors, are increasingly turning the contemporary world economic space into a single global market. All this, first of all, strikes at the formed and institutionalized social bonds and relationships, both within individual states and on the scale of interstate associations. Against this background, international organizations and their structural subdivisions, such as the UN, OSCE, etc. appreciably lose their prestige and weight.

At the same time, new associations are formed, such as for example the European Union (EU) with its institutions, the World Trade Organization (WTO), and others. Activities of the pre-existing international organizations embodied in various structures of the Council of Europe (COE), the International Monetary Fund (IMF), and NATO are essentially increased. Their functioning has significant impact on both the reorientation and displacement of individual states and even entire regions to the periphery of the world civilization space. 
In this regard, there is a marked decline in the role of national states in these processes, taking place against the background of the delegation of some of its most important functions to the newly created international power structures. This, of course, cannot but lead to the loss of national sovereignty by these states and pose a threat even to their territorial integrity, and in consequence, creates favorable conditions for attempts and even open interference in their internal affairs on the part of third forces.

In some cases, this has destructive impact on the national security of these states, provoking various kinds of anti-state protests in these countries. At that, the multiplying internal problems are supplemented by new ones, caused by inflammatory actions from the outside, which are most often aimed at organizing a confrontation to the activities of government agencies on the part of all those who are not completely satisfied with it for any reason. Therefore, the latter, with this kind of aiding, are trying to take advantage of the opportunities being created to satisfy their ambitious claims.

Today in the world there is a radical arrangement not only of global economic, legal, and cultural space. At the same time, searches for models of the so-called multipolar arrangement of the world in general are going on. However, this process itself, projected on the organization of both individual life of a single person, and on the activities of any kind of social structures, turns into a truly multipolar chaos in the life of society.

Indeed, in this case, first of all, new alien ideals, norms, and values are imposed against the will to people's traditional way of life, entrenched largely due to certain territorial features or regional specifics. In fact, their open westernization takes place, which consists in the reorientation of people's lives according to the models of Western European or Anglo-American standards.

All of the above confirms the assumption that globalization should be considered a major factor in the escalation of regional conflicts.

\subsection{External aggravation of conflictogenity as a factor of regional conflicts' escalation}

It should be noted that today, along with the use of the so-called hard power, soft power finds application more than ever. As known, "hard power" usually manifests in economic, administrative, and even open armed impact. "Soft power" is a power that is implemented in the form of a certain communicative impact, in which process the imposed behavior is perceived by the recipient as his own free and voluntary choice, even bringing joy and pleasure (Rusakova, 2015, p. 7).

And all this is done under the onslaught of increasingly manifested policy of mondialism. At the same time, the values of ethnic, religious and even national character are categorically declared to be less significant than the so-called universal values. At the same time, social rules, laws, and other regulations in general, due to which, in fact, the social activities of people are carried out, ensuring today the functioning of various life spheres of the contemporary world civilization space, undergo changes.

However, this desire to rearrange the whole world in order to "improve" it does not take into account one significant circumstance. This is hardly feasible in principle, because for example, "according to analysts of the UN Development Program, at the beginning of the 21st century, the total wealth of 225 richest people in the planet exceeded one trillion USD that was equal to the annual income of 2.5 billion poor people, who make up $47 \%$ of the world's population" (Osmova, 2006). And this contrast has an increasing tendency to deepen (Tvaronavičienè, Gatautis 2017).

In such an environment, the "privileged" countries are very zealous of the emergence of all that can pose a threat to their position in the context of globalization. At that, any means are in the course, even up to the most inhumane. However, this is increasingly being done under the slogan of "grafting democracy" to more "backward" countries in terms of civilization. 
Against this background, the contours of a new vector in the escalation of conflictogenity in various spheres of present-day international relations are becoming more visible. Its essence is the increasingly applied policy of "demonization of the designated threat", which is presented in every possible way as having features that pose a danger, at least, to all democratic gains already existing in the world. At that, anyone can become the contender for this role of "outcast": a specific socio-political leader, the whole state, or even a particular religion. For the sake of this, the principles of morality and norms of international law, and interstate agreements are ignored. These purposes are pursued in the framework of "double standards" policy. The adoption of important political decisions is carried out based on evidence grounds not adopted throughout the civilized world, but simply laid out in the mass media, or based on information, opinions, and even rumors posted on the Internet.

One of the most popular methods of escalation of conflictogenity at regional level in recent years has been the export of so-called "color revolutions", which is the local initiation of small-scale (regional in nature) conflicts through the organization of mass riots, anti-state coups, and various kinds of putsches organized on the basis of proven technology.

In these regions, the focus is made on the opposition forces. The choice of these regions, as a rule, is not accidental. First of all, they are attractive because of the wealth of natural resources, geopolitical location, and imaginary or real threat to the interests of stronger players in the international arena, etc.

The initiators of the "color revolutions" do not stop at nothing to stimulate and intensify counter-activity to the policy, which is currently carried out by the authorities. In recent years, especially in Islamic countries, there has been an increasing emphasis on inciting hatred among the population on religious grounds, to some extent related to the crisis of the identity of Islamic communities. To aggravate the situation, various (even artificially organized) extremist groups and members of international terrorist organizations have become increasingly involved.

All this is deliberately used to destabilize economic, political, religious, and other life spheres within certain territories of specific states or even certain regions of the entire geopolitical space. Usually, the main objective consists in influencing the policy pursued by the existing authorities; ousting from power or eliminating the leadership, up to its physical liquidation; bringing to power forces loyal to external actors, etc. This is clearly evidenced by the events that took place in Iraq, Afghanistan, Libya, Syria, Egypt, and a number of other countries.

However, the consequences of external intervention are a harbinger of almost uncontrollable chaos in the lives of a number of states, even those that are far from the epicenter of conflicts. The mass influx of refugees to Europe provoked by such events has already caused a complex of problems for most of its countries, which are not connected only with one socio-economic sphere.

Actions by a number of states that rely in their politics on the rampant of "protestocracy" in order to reformat the dominant paradigm and regional way of life of a number of states in the Middle East and the African continent acquire today a significant role in changing the configuration of the manifestation of global instability, which further emphasizes its unmanageable nature.

All of the above confirms the assumption that the aggravation of the situation in the region caused by external influence is a major factor in the escalation of regional conflicts.

\section{Conclusion}

The results of the study confirmed the assumption that the analysis of regional conflicts as an attribute of global instability is more effective when using the methodology of problematization. At that, the globalization processes and external aggravation of conflict in the region should be considered the main factors of escalation of these conflicts. 
In conclusion, it should be noted that one of the features of the present moment is that the intensity of the manifestation of confrontation is increasing also due to the fact that the countries, occupying today a leading position in the world, are increasingly trying to assert their claims to kind of "subjectivity", not particularly taking into account the interests of their environment. When manifesting their power and superiority, they not only seek to benefit from the conflictogenic nature of the globalization process, but manifest their self-centeredness even more to destabilize situation in the world. At that, they seek to demonstrate their rivalry not so much in their own, but in someone else's territory.

In society, conflicts exactly of the regional format, even in the most inhumane manifestations, are becoming today the most popular form of solving many important life problems. But the negative consequences of the transformation of these regions into the theater of war make even more chaos in the dynamics of social processes. The regional conflicts themselves, due to their unpredictability and uncontrollability, are increasingly transformed from a means of solving problems even at the local level to an attribute of a threat to stability in the world in general.

A vector of social self-organization of society could serve an alternative to the existing models of multipolar arrangement of the world. In this case all of its physical and legal subjects, manifesting natural counter-activity between each other, should attempt to return this counter-activity to the framework of the subject-to-subject relations.

\section{References.}

Anisimov, O.S. (1991). Novoe upravlencheskoe myshlenie: sushchnost'i puti formirovaniya [New management thinking: Essence and ways of formation]. Moscow: Economy, $352 \mathrm{p}$.

Anisimov, O.S. (2008). Metodologicheskij slovar' [Methodological dictionary], (4th ed.). Moscow, 414 p.

Baturin, V.S., \& Shakirov, S.E. (2014). Paradigma social'noj samoorganizacii kak sistemoobrazuyushchaya proyavleniya konfliktov v obshchestve [Paradigm of social self-organization as a system-forming manifestation of conflicts in society]. Conflictology, S, 78-80.

Coser, L. (2000). Funktsii sotsial'nogo konflikta [The functions of social conflict]. Moscow: Idea-Press, House of Intellectual Books, $208 \mathrm{p}$.

Kasymov, K. (2018). Istoriya reform, dostizhenij i neudach glavnogo policejskogo Kazahstana [History of reforms, achievements, and failures of the chief police officer of Kazakhstan]. Retrieved June 1, 2019, from https://informburo.kz/stati/kalmuhanbet-kasymovistoriya-reform-dostizheniy-i-neudach-glavnogo-policeyskogo-kazahstana.html

Kazansky, R.; Andrassy, V. 2019. Conflict resolution approaches towards smart sustainability of internal relations. Entrepreneurship and Sustainability Issues 6(3): 1268-1284. https://doi.org/10.9770/jssi.2019.6.3(29)

Konflikt v Temirtau [The conflict in Temirtau: Chronic stage] (2012). Retrieved June 1, 2019, from https://vesti.kg/index.php?Itemid $=100 \&$ id $=11863 \&$ option $=$ com_k2\&view $=$ item

Konflikt v Zapadnom Kazahstane [The conflict in Western Kazakhstan]. The Eye of the World... (2012). Retrieved June 1, 2019, from https://oko-planet.su/politik/politiklist/154617-konflikt-v-apadnom-kazahstane.html

Osmova M.N. (2006). Globalizaciya mirovoj ehkonomiki, social'no-ehkonomicheskoe neravenstvo i izmeneniya v stratifikacii obshchestva [Globalization of the world economy, socio-economic inequality, and changes in the stratification of society]. Retrieved June 1, 2019, from https://economy-ru.com/mirovaya-ekonomika-uchebnik/globalizatsiya-mirovoy-ekonomiki-sotsialno-54165.html

Prause, G.; Tuisk, T.; Olaniyi. 2019. Between Sustainability, Social Cohesion and Security. Regional Development in North-Eastern Estonia, Entrepreneurship and Sustainability Issues 6(3): 1135-1154. http://doi.org/10.9770/jesi.2019.6.3(13)

Rusakova, O.F. (2015). Soft paver: teoriya, resursy, diskurs [Soft power: Theory, resources, discourse]. Yekaterinburg: Discourse-PI Publishing House, 376 p.

Svetlov, V.A. (2012). Vvedenie v edinuyu teoriyu analiza i razresheniya konfliktov: Uchebnoe posobie [Introduction to the unified theory of analysis and conflict resolution: Textbook] (3nd ed.). Moscow: LIBROKOM Book House, 304 p.

Turen, S.; Abdulla, M.; Farooq, M.O.; Elsoud, M.S.A. 2019. Causes of Non-Performing Loans: The Experience of Gulf Cooperation 
Council Countries, Entrepreneurship and Sustainability Issues 6(4): 1955-1974. http://doi.org/10.9770/jesi.2019.6.4(29)

Turovsky, R.F. (2001). Osnovy i perspektivy regional'nyh politicheskih issledovanij [Fundamentals and prospects of regional political studies]. POLIS, 1, 138-157.

Tvaronavičienė M. 2018b. Towards internationally tuned approach towards critical infrastructure protection, Journal of Security and Sustainability Issues 8(2): 143-150. https://doi.org/10.9770/jssi.2018.8.2(2)

Tvaronavičienė, M. 2018a. Toward efficient policy making: forecasts of vulnerability to external global threats, Journal of Security and Sustainability Issues 7(3): 591-600. https://doi.org/10.9770/jssi.2018.7.3(18)

Tvaronavičienė, M; Gatautis, R. 2017. Peculiarities of income distribution in selected countries, Economics and Sociology 10(4): 113123. https://doi.org/10.14254/2071-789X.2017/10-4/9

Ushakov, D.N. Bol'shoj tolkovyj slovar' [Big explanatory dictionary]. Retrieved June 1, 2019, from http://classes.ru/all-russian/russiandictionary-Ushakov-term-27397.htm

This work is licensed under the Creative Commons Attribution International License (CC BY). http://creativecommons.org/licenses/by/4.0/ 